\title{
Pharmacognosy \\ Determination of the metabolic profile of Solidago canadensis using UFLC-PDA-ESI-TOF
}

\author{
Andressa Maia Kelly ${ }^{1,2}$, Temistocles Barroso de Oliveira $^{1}$ \& Simone Sacramento Valverde ${ }^{1,3}$
}

\begin{abstract}
Species in the Solidago genus are used worldwide due to the therapeutic activities of their flavonoids and terpenoids. Its anti-inflammatory, antirheumatic, analgesic, diuretic, aquaretic, wound-healing properties as well as its ability to relieve burn and insect bites allow use in a variety of situations. This study was carried out to determine the metabolic profile of Solidago canadensis inflorescences (SCAI) to identify the species commercialized in Rio de Janeiro, RJ, Brazil, and evaluate the medicinal potential compared to S. chilensis and SCAI, which is used in North America and Europe. The UFLC-PDA-ESI-TOF revealed the metabolic profile of SCAI, finding the pseudo-molecular ions and characteristic fragments, mainly flavonols (10) such as quercetin, kaempferol, isorhamnetin, and its glycosides, as well as chlorogenic acid (CA). Eleven substances were identified, confirming the compatibility of the metabolic profile presented in varieties canadensis and scabra of european S. canadensis. The both contain the same flavonoid aglycones, and their glycosides are important chemical and biological markers for extracts and products based on species of the genus Solidago. UFLC-PDA-ESI-TOF characterized the extracts, which can help with quality control of raw plant materials and commercialized phytotherapeutics as well as for development of new products and phytomedicines.

Key words: flavonoids, metabolic profile, quality control, Solidago canadensis, UFLC-PDA-ESI-TOF.

\section{Resumo}

Espécies de Solidago são utilizadas mundialmente pelas atividades terapêuticas dos seus flavonoides e terpenoides, ações anti-inflamatória, antirreumática, analgésica, diurética, aquarética, cicatrizante de feridas e queimaduras e em picadas de insetos, que permitem sua utilização em substituição uma à outra. Para determinação do perfil metabólico (PM) de inflorescências de Solidago canadensis (SCAI) comercializada no Rio de Janeiro, RJ e avaliação do seu potencial medicinal frente à S. chilensis e à SCAI utilizada na América do Norte e Europa, a UFLC-PDA-ESI-TOF é de grande relevância, resolução e rapidez e revelou, através do íons pseudo-moleculares e fragmentos característicos, o PM de SCAI, formado principalmente flavonóis: quercetina, kaempferol, isoramnetina e seus glicosídeos, além do ácido clorogênico (AC), aos quais são atribuídas importantes atividades biológicas de S. chilensis. Onze substâncias, dentre elas 10 flavonóis e o AC, confirmaram a compatibilidade do PM apresentado com as variedades canadensis e scabra da S. canadensis europeia, que apresenta as mesmas agliconas e glicosídeos, marcadores químicos e biológicos para extratos e produtos à base de espécies do gênero Solidago. UFLC-PDA-ESI-TOF permite a caracterização de extratos e contribui para o controle da qualidade de matérias-primas vegetais e fitoterápicos comercializados e para o desenvolvimento de novos produtos e fitomedicamentos.

Palavras-chave: flavonoides, perfil metabólico, controle de qualidade, Solidago canadenses, UFLC-PDAESI-TOF.
\end{abstract}

\footnotetext{
${ }^{1}$ FIOCRUZ, Pharmaceutical Technology Institute, R. Sizenando Nabuco 100, 21041-250, Rio de Janeiro, RJ, Brazil.

${ }^{2}$ ORCID: < https://orcid.org/0000-0002-4006-811X>

${ }^{3}$ Author for correspondence: simone.valverde@fiocruz.br
} 


\section{Introduction}

The ethnopharmacological use of species of the Solidago genus has long been used throughout the world and is related to the therapeutic activities of its flavonoids and terpenoids. Some qualitative and quantitative differences exist in anti-inflammatory, bacteriostatic, and aquaretic properties of different goldenrod species (Foster \& Tyler 1999; Avila \& Fetrow 2000; Robbers \& Tyler 2000).

Solidago species are widely used in Europe to treat urinary tract inflammations, preventing formation or facilitating elimination of kidney stones (Robbers \& Tyler 2000; Apáti et al. 2002; Gastaldi et al. 2018). This species naturally occurs throughout the world: Solidago canadensis in North America; Solidago virgaurea in Europe; Solidago gigantea in Asia; and Solidago chilensis in South America (Robbers \& Tyler 2000; Sutovská et al. 2013). These species are present in pharmacopoeias, scientific literature, and pharmaceuticals. Solidago is indicated as an anti-inflammatory, antirheumatic, analgesic, diuretic, and aquaretic agent, as well as for healing wounds, burns, and insect bites. The species are often used interchangeably (Robbers \& Tyler 2000; Apáti et al. 2002; Apáti 2004; Sutovská et al. 2013; Oliveira et al. 2017; Gastaldi et al. 2018; Valverde et al. 2012).

In Brazil, S. chilensis is the official species of the first edition of FB (Brasil 1926) and on the list of interesting species of the Brazilian public health system (Brasil 2009) with the previous synonymy: S. microglossa. It is also on the therapeutic herbal list of many Brazilian cities, such as RJ and SP (SMSDC 2010), while S. canadensis is commonly used for ornamental purposes.

To analyze complex plant extracts and fractions, characterizing their contents without isolation of the substances, the metabolomic approach has been used with different chromatographic and spectroscopic techniques.

This work was conducted to determine the metabolic profile of $S$. canadensis inflorescences (SCAI) compared to the officinal Brazilian species S. chilensis (SCMI) in order to the evaluate their medicinal potential compared to the $S$. canadensis used in North America and Europe and S. chilensis used in Brazil.

\section{Material and Methods}

\section{Solvents and chemicals}

Solidagenone, quercetin, and quercitrin previously isolated from $S$. chilensis inflorescences and identified through NMR, IR, and MS spectra (Valverde et al. 2009; Oliveira \& Valverde 2017), and five flavonoids and chlorogenic acid used to investigated the SCAI content and to determine its metabolic profile were the pure standard (Sigma$\mathrm{Merck}^{\mathrm{TM}}$ ). All the solvents used were AR (analytical research grade) or spectral grade according with the analysis.

\section{Plant material and extraction}

Solidago canadensis inflorescences were purchased in June 2018 at CADEG (Rio de Janeiro Municipal Market) with the popular description: Tango and the scientific description presumed by the seller as Solidago canadensis. The inflorescences (102 g) were dried and pulverized in a knife mil and extracted according with our previous work, with ether: ethanol (1:1), by dynamic maceration, filtered and concentrated to dryness under reduced pressure at $40^{\circ} \mathrm{C}$ furnishing $4.1 \mathrm{~g}$ of the inflorescences extract (yield 4.2\%) (Valverde et al. 2009).

\section{Metabolic profile analysis}

The TLC analysis was performed using 30 $\mu \mathrm{L}$ aliquots of the raw extract and $10 \mu \mathrm{L}$ of the pure standard which were eluted with BAW (n -butanol:acetic acid:water - upper phase) (4:1:5) for phenolics and flavonoids and with hexane: ethyl acetate (8:2) for other phytochemicals. The TLCs were physically developed under UV lamp and with reagent solutions, such as NP-PEG for phenolics and flavonoids, to characterize their different phytochemicals using sulfuric anisaldehyde (Wagner \& Bladt 1996). TLC plates precoated with silica gel F254 (Merck ${ }^{\mathrm{TM}}$ ) were used.

The UFLC-PDA-ESI-TOF analysis was carried out on a KINETEX ${ }^{\mathrm{TM}}(100 \times 3 \times 2.6 \mu \mathrm{m})$ at $30{ }^{\circ} \mathrm{C}$ with a solution of TFA (trifluoroacetic acid) (A) and acetonitrile (B) as mobile phase (flow $0.8 \mathrm{~mL} / \mathrm{min}$ ), in a Shimadzu Nexera 30AD equipped with a quaternary pump, detector with photodiode arrangement and automatic sampler. MS was performed using a Bruker Compact Mass Spectrometer $\left(\right.$ Bruker $^{\mathrm{TM}}$ ) spectrometer with electrospray ionization interface (ESI) and quadrupole ion trap analyzer to identify directly and simultaneously the presence of flavonoids in the samples, extract, and pure substances. The ESI-MS spectrum was acquired in the negative mode for the sample and reference compounds $\left(\right.$ Sigma $\left.^{\mathrm{TM}}\right)$. Parameters: gas temperature $220{ }^{\circ} \mathrm{C}$, 
capillary voltage at $4.5 \mathrm{kV}$, gas mist $\left(\mathrm{N}_{2}\right)$, flow 10 $\mathrm{L} / \mathrm{min}$, and pressure at 5.0 Bar. MS was obtained in the full-scan mode in the $50-800 \mathrm{~m} / \mathrm{z}$ range.

\section{Results and Discussion}

The analysis of SCAI extract compounds by UFLC-PDA-ESI-TOF (Fig. 1) revealed its metabolic profile through the pseudo-molecular ions $[\mathrm{M}-\mathrm{H}]^{-},[\mathrm{M}+\mathrm{Cl}]^{-},\left[\mathrm{Agly}-\mathrm{H}-\mathrm{CO}_{2}-\mathrm{CO}\right]^{-}$, [Agly$\left.\mathrm{H}-\mathrm{CO}_{2}-\mathrm{CO}\right]^{-},[\mathrm{M}+2 \mathrm{Cl}]^{-}$, [M-Rha], [M-Gly], and their characteristic ion fragments.

The structures of these compounds were confirmed by comparing with standard pure compounds such as quercetin, kaempferol, quercitrin, isoquercitrin, and chlorogenic acid, as well as their fragmentation ESI-MS-TOF pattern in experiments and literature data (Saldanha et al. 2013; Brito et al. 2014; Kim et al. 2017; Jang et al. 2016).

Only three aglycone, detected by the pseudomolecular anion $[\mathrm{M}-\mathrm{H}]$, , quercetin at $\mathrm{m} / \mathrm{z}$ 301 , kaempferol at $m / z 285$, and isorhamnetin at $\mathrm{m} / \mathrm{z} 315$ were identified in the flavonoid content.

All these are flavonols (Tab. 1), and their occurrence was previously reported in the Solidago genus (Apáti et al. 2002, 2004) and its glycosides, but using HPLC. These flavonoids are responsible to the important biological activities of $S$. chilensis.

The characteristic loss of the sugars in the compounds confirmed the presence of glucose $(-162)$, rhamnose (-146), and rutinose (-308). The identification of all MS detected and identified compounds present in SCAI extract are presented in Figure 2 and Table 1 and explained below.

\section{Identification of compounds}

Major compounds detected through the UFLC analysis of the SCAI extract are in Table 1. Peak 1 was identified as chlorogenic acid, $\lambda$ max 203, 284, and $327 \mathrm{~nm}$, with pseudomolecular anion [M-H] - at $m / z 353$ and $\mathrm{MS}^{2}$ fragment at $\mathrm{m} / \mathrm{z}$ 161 , corresponding to the [M-192]- loss of quinic acid. Peak 4 was identified as quercetin-3-O- $\beta$ D-rutoside (rutin), with pseudomolecular anion at $m / z 609, \lambda \max 255,353 \mathrm{~nm}$, and $\mathrm{MS}^{2}$ fragment at $\mathrm{m} / \mathrm{z} 447$, corresponding to the [M-162]- (loss of the glycose) Gly portion. Peak 5 represented quercetin-3-O- $\beta$-D-glycoside (isoquercitrin) [M$\mathrm{H}]^{-}$at $m / z$ 463, $\lambda \max 207,309,256,266,352 \mathrm{~nm}$, and $\mathrm{MS}^{2}$ at $m / z 292$ corresponding to [M-171]', a $\mathrm{B}_{2}^{+}$. fragment, due to a RDA (Retro Diels-Alder)

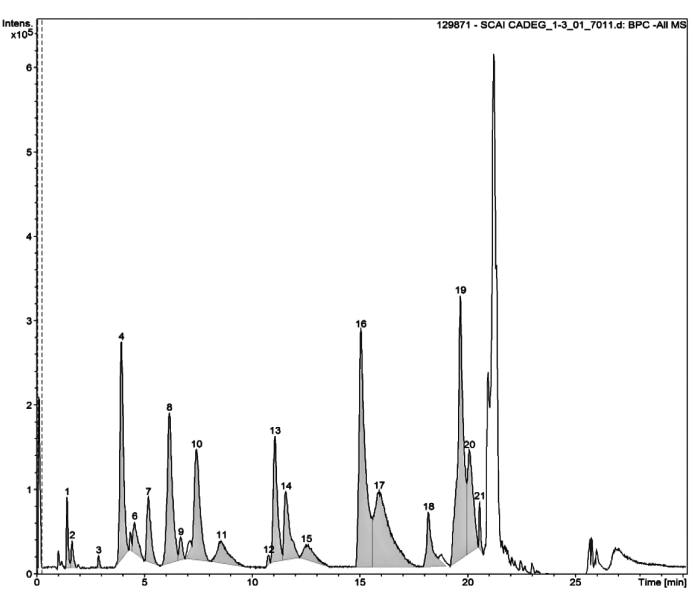

Figure 1 - All MS data, UFLC chromatogram (in negative mode) of phenolic compounds of extract of $S$. canadensis inflorescences.

reaction and $\mathrm{MS}^{3}$ at $\mathrm{m} / \mathrm{z} 231$, corresponding to [Agly-H-CO $\left.{ }_{2}-\mathrm{CO}\right]^{\prime},($ Agly $=$ aglycone $)$, quercetin $(\mathrm{m} / \mathrm{z}$ 301). Peak 8 showed a pseudomolecular ion at $\mathrm{m} / \mathrm{z} 593$, an adduct [Agly $+2 \mathrm{Cl}]^{-}$ion at $\mathrm{m} / \mathrm{z} 353$ and $\mathrm{MS}^{2}$ ions at $\mathrm{m} / \mathrm{z}$ 515: [M-78]- Peak 10 with a pseudomolecular anion a 505 was identified as quercetin-3-O-6"-acetyl glycoside ( $\mathrm{MS}^{2}$ ions at $\mathrm{m} / \mathrm{z}$ 587: [M+81]; 301: [M-204], and 431: [M-74], respectively. Peak 11, with a pseudomolecular anion at $\mathrm{m} / \mathrm{z} 623$ and typical fragments $\mathrm{MS}^{2}$ at $\mathrm{m} / \mathrm{z}$ 505: [M-120]; 431, 283, corresponded to $\left[\mathrm{M}\right.$-rut- $\left.-\mathrm{OCH}_{3}\right]$ and 240 . Peak 13 was identified as kaempferol-3-6"-acetyl- $\beta$ glycoside with pseudomolecular ions at $\mathrm{m} / \mathrm{z} 489$ and $\mathrm{MS}^{2}$ ions at $m / z 571$ and 255. Peak 14 indicated a pseudomolecular ion at $m / z 519$ and an aglycon ion (quercetin) at $\mathrm{m} / z 301$ (MS': [M-rha-acetyl], which were identified as quercetrin (quercetin3 -O- $\beta$-D-rhamnoside). Peak 16 presented only the pseudomolecular ion [M-H] at $m / z 285$ identified as isorhamnetin with $[\mathrm{M}-\mathrm{H}]^{-}$at $m / z 317$ and $\mathrm{MS}^{2}$ ion at $m / z 285$, corresponding to $\left[\mathrm{M}-\mathrm{CH}_{3}\right]^{-}$(Jang et al. 2016; Marczak et al. 2016; Pinheiro \& Justino 2012; Saldanha et al. 2013; March et al. 2006).

\section{Conclusions}

The UFLC-PDA-ESI-TOF allowed the detection and identification of 13 phenolic compounds in the SCAI extract. Altogether, 11 flavonols were found including: six quercetin derivatives (peaks $4,5,6,9,10$, and 14), three kaempferol derivatives (peaks 8, 13, and 16), 
Table 1 - Peak assignments, UV, and MS data (in negative mode) of phenolic compounds extracted from Solidago canadensis inflorescences obtained through UFLC-PDA-ESI-TOF.

\begin{tabular}{|c|c|c|c|c|c|c|}
\hline $\begin{array}{c}\text { Peak } \\
\mathbf{n}^{0}\end{array}$ & $\underset{(\min )}{\mathrm{RT}}$ & $\begin{array}{l}m / z \\
\operatorname{Max}\end{array}$ & {$[\mathrm{M}-\mathrm{H}]^{-}$} & $\mathrm{UV} \mathrm{L}_{\max }(\mathrm{nm})$ & $\begin{array}{c}\text { Chracteristic } \\
\text { ion fragments } \\
(m / z)\end{array}$ & Identification \\
\hline 1 & 1.4 & 263.11 & & & & NI \\
\hline 2 & 1.6 & 353.09 & 353.09 & $203,284,327$ & $263.11,161.06$ & Chlorogenic acid \\
\hline 3 & 2.9 & 445.21 & - & - & - & NI \\
\hline 4 & 3.9 & 609.15 & 609.15 & 255,353 & 447.10 & Rutin (quercetin-3-O- $\beta$-D-rutinoside) \\
\hline 5 & 4.3 & 463.09 & 463.09 & $207,309,256,266,352$ & 231.97, 292.99 & Isoquercitrin (quercetin-3-O- $\beta$-D-glucoside) \\
\hline 6 & 45 & 609.15 & 609.15 & 255,353 & 447.10 & * Rutin Isomer \\
\hline 7 & 5.2 & 515.12 & 515.12 & $203,284,327$ & 353.09 & Chlorogenic acid glucoside \\
\hline 8 & 6.2 & 593.16 & 593.16 & $207,326,238,469$ & $\begin{array}{l}\text { 675.16, 515.12, } \\
353.09,231.97\end{array}$ & Nicotiflorin (kaempferol-3-O- $\alpha$-L-rutinoside) \\
\hline 9 & 6.7 & 447.09 & 447.09 & $207,309,256,266,352$ & $\begin{array}{c}516.13,353.09 \\
243.97\end{array}$ & *Quercitrin Isomer \\
\hline 10 & 7.4 & 505.10 & 505.10 & $207,309,256,266,352$ & $587.10,431.10$ & Quercetin-3-O-6"-acetyl glucoside \\
\hline 11 & 8.6 & 505.10 & 623.17 & $254,297,353$ & $\begin{array}{l}\text { 505.10, 431.10, } \\
283.27,240.97\end{array}$ & $\begin{array}{l}\text { Narcissin (isorhamnetin-3-O- } \alpha-\mathrm{L}- \\
\text { rhamnopyranosyl-( }(1 \rightarrow 6)-\mathrm{O}-\beta-\mathrm{D}- \\
\text { glucopyranoside) }\end{array}$ \\
\hline 12 & 10.8 & 239.16 & 505.10 & - & $239.16,321.17$ & NI \\
\hline 13 & 11.1 & 489.11 & 489.11 & 265,347 & $571.11,255.23$ & kaempferol-3-O-acetyl- $\beta$-glucoside \\
\hline 14 & 11.6 & 301.04 & 519.12 & $207,255,350,469,672$ & 301.04 & Quercitrin (quercetina-3-O- $\beta$-D-rhamnoside) \\
\hline 15 & 12.5 & 301.04 & 519.12 & - & 301.04 & NI \\
\hline 16 & 15.0 & 285.04 & 285.04 & 265,347 & - & kaempferol \\
\hline 17 & 15.9 & 285.04 & 315.05 & 253,344 & 285.04 & Isorhamnetin \\
\hline 18 & 18.2 & 329.23 & - & - & - & NI \\
\hline 19 & 19.7 & 785.36 & - & - & 392.17 & NI \\
\hline 20 & 20.1 & 785.36 & - & - & 392.17 & NI \\
\hline 21 & 20.6 & 299.02 & - & - & $\begin{array}{c}\text { 785.36, 601.07 } \\
299.02\end{array}$ & NI \\
\hline
\end{tabular}

$*=$ Not Identified

and two isorhamnetin derivatives (peaks 11 and 17) (Tab. 1), as well as chlorogenic acid and its derivative (peaks 2 and 7).

The results confirmed, with reference substances, fragmentation pattern, UV-vis max, and literature data, that the metabolic profile obtained was similar to the canadensis and scabra varieties of $S$. canadensis found in Europe, which presents the same flavonoid aglycones and large amounts of their glycosides as described by Apáti (2004).
The UFLC-PDA-ESI-TOF fingerprinting is presently used for rapid quality control purposes to evaluate commercially available medicinal plants widely used by the population, to simultaneously determine their metabolic markers and predict the biological plant performance, their identity, and the confirmation of the metabolic pattern of this plant obtained in a popular market with literature data described for $S$. canadensis.

This work is basis for the quantification of the identified flavonoids, to determine the 
Chlorogenic acid<smiles>O=C(/C=C/c1ccc(O)c(O)c1)OC1CC(O)(C(=O)O)C[C@H](O)[C@@H]1O</smiles>

Rutin
(quercetin-3-O- $\beta$-D-rutinoside)



Isoquercitrin

(quercetin-3-O- $\beta-D-$ glycoside)
Quercetin-3-0-6"-acetyl glycoside

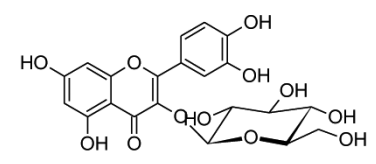

C

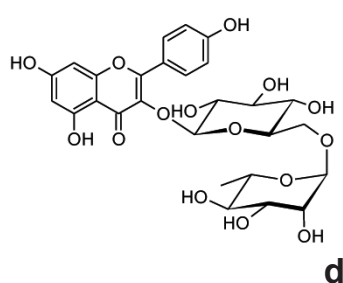

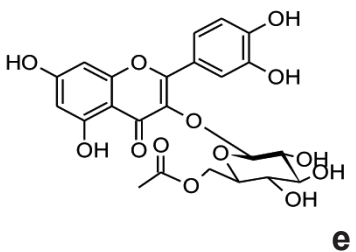

Quercitrin (quercetina-3-O- $\beta$-D-rhamnoside)

Kaempferol

Narcissin

(isorhamnetin-3-O- $\alpha-L-$ rhamnopyranosyl$(1 \rightarrow 6)-O-\beta$-D-glycopyranoside)



kaempferol-3-6"-O-acetyl- $\beta$ glycoside<smiles></smiles><smiles></smiles><smiles>O=c1c(O)c(-c2ccc(O)cc2)oc2cc(O)cc(O)c12</smiles><smiles>COc1cc(-c2oc3cc(O)cc(O)c3c(=O)c2O)ccc1O</smiles>

Figure 2 - a-j. Structure of compounds identified in Solidago canadensis inflorescences.

biological marker, to the standardization of the marketed SCAI plant extract, and also, to further development of an herbal medicine from SCAI.

\section{Acknowledgements}

The authors are grateful to CNPq (National Council for Scientific and Technological Development) for financial support - PROEP and scholarship to AMK.

\section{References}

Andersen M \& Markham KR (2006) Flavonoids: chemistry, biochemistry and applications. CRC Press Taylor \& Francis Group, Boca Raton. 1212p. Apáti P, Szentmihályi K, Balázs A, Baumann D, Hamburger M, Kriston TSZ, Szoke E \& Kery A (2002) HPLC analysis of the flavonoids in pharmaceutical preparations from Canadian goldenrod (Solidago canadensis). Chromatographia Supp. Vol. 56. Springer, Basel. Pp. S65-S68.
Apáti P, Houghton PJ \& Kéry A (2004) HPLC investigation of antioxidant components in Solidago herba. Acta Pharmaceutica Hungarica 74: 223-31.

Beck JJ, Smith L \& Baig N (2014) An overview of plant volatile metabolomics, sample treatment and reporting considerations with emphasis on mechanical damage and biological control of weeds. Phytochemical Analysis 25: 331-341.

Brasil - ANVISA (1926) Farmacopeia brasileira. Cia. Editora Nacional, São Paulo. 1149p.

Brasil - Ministério da Saúde (2009) Relação de plantas de interesse ao SUS. Available at <http://bvsms. saude.gov.br/bvs/sus/pdf/marco/ms_relacao_ plantas_medicinais_sus_0603.pdf $>$. Access on $0 \overline{3}$ April 2019.

Brito A, Ramirez JE, Areche C, Sepúlveda B \& Simirgiotis MJ (2014) HPLC-UV-MS Profiles of phenolic compounds and antioxidant activity of fruits from three citrus species consumed in Northern Chile. Molecules 19: 17400-17421.

Eugster PJ, Guillarme D, Rudaz S, Veuthey JL, Carrupt PA \& Wolfender JL (2011) Ultra high pressure liquid 
chromatography for crude plant extract profiling. Journal of Association of Official Analytical Chemists International 94: 51-70.

Gastaldi B, Catalán CAN, Silva-Sofrás FM \& González SB (2018) Solidago chilensis Meyen (Asteraceae), a medicinal plant from South America. A comprehensive review: ethnomedicinal uses, phytochemistry and bioactivity. Boletín Latinoamericano y del Caribe de Plantas Medicinales y Aromáticas 17: 17-29.

Jang GH, Kim HW, Lee KM, Jeong YS, Bak AR, Lee DJ \& Kim JB (2016) Characterization and quantification of flavonoid glycosides in the Prunus genus by UPLC-DAD-QTOF/MS. Saudi Journal of Biological Sciences 25: 1622-1631.

Kim N, Shin YJ, Park S, Yoo G, Kim Y, Yoo HH \& Kim SH (2017) Simultaneous determination of six compounds in Hedera helix L. Using UPLC-ESIMS/MS. Chromatographia 80: 1025-1033.

Knox JH (1977) Practical aspects of LC theory. Journal of Chromatographic Science 15: 352-364.

Robbers JE \& Tyler E (2000) Tyler's herbs of choice: the therapeutic use of phytomedicinals. The Haworth Press, New York. 312p.

March RE, Lewars EG, Stadey CJ, Miao X-S, Zhao $\mathrm{X} \&$ Metcalfe CD (2006) A comparison of flavonoid glycosides by electrospray tandem mass spectrometry. International Journalos Mass Spectrometry 248: 61-85.

Marczak L, Znajdek-Awi zen P \& Bylka W (2016) The use of mass spectrometric techniques to differentiate isobaric and isomeric flavonoid conjugates from Axyris amaranthoides. Molecules 21: 1229.

Oliveira TB \& Valverde SS (2017) Quercetin and quercetin derivatives flavonoids extraction and isolation from Solidago chilensis Meyen inflorescences. Vol. 29. Infarma, Brasília. Pp. S577-S577.

Oliveira TB, Silva FC, Kelly AM \& Valverde SS (2017)
Solidago medicinais. Revista Brasileira de Plantas Medicinais 19: 168-176.

Pinheiro PF \& Justino JC (2012) Structural analysis of flavonoids and related compounds - a review of spectroscopic applications. Phytochemicals - a global perspective of their role in nutrition and health. DOI: 10.5772/29152.

Saldanha LL, Vilegas W \& Dokkedal AL (2013) Characterization of flavonoids and phenolic acids in Myrcia bela Cambess. Using FIA-ESI-IT-MS ${ }^{\mathrm{n}}$ and HPLC-PAD-ESI-IT-MS combined with NMR. Molecules 18: 8402-8416.

SMSDC - Secretaria Municipal de Saúde e Defesa Civil (2010) Prefeitura da Cidade do Rio de Janeiro, Rio de Janeiro. 15p.

Sutovská M, Capek P, Kocmálováa M, Franová S, Pawlaczykc I \& Gancarz R (2013) Characterization and biological activity of Solidago canadensis complex. International Journal of Biological Macromolecules 52: 192-197.

Valverde SS, Azevedo SS \& Tomassini TCB (2009) Utilização de CLAE, como paradigma na obtenção e controle do diterpeno solidagenona a partir de inflorescências de Solidago chilensis Meyen (arnica brasileira). Revista Brasileira de Farmácia 90: 196-199.

Valverde SS, Oliveira TB \& Souza SP (2012) Solidago chilensis Meyen (Asteraceae). Revista Fitos 7: 131-136.

Wolfender JL, Glauser G, Boccard J \& Rudaz S (2009) MS-based plant metabolomic approaches for biomarker discovery. Nat. Prod. Commun. 4: 1417-1430.

Wolfender JL, Marti G, Thomas A \& Bertrand S (2015) Current approaches and challenges for the metabolite profiling of complex natural extracts. Journal of Chromatography A 1382: 136-164. 